\title{
Retesting of Liquefaction/Nonliquefaction Case Histories in the Imperial Valley
}

\author{
Robb E. S. Moss, ${ }^{\text {a) }}$ M.EERI, Brian D. Collins, ${ }^{\text {b) }}$ M.EERI, and Daniel H. Whang, ${ }^{\text {c) }}$ \\ M.EERI
}

This paper describes the retesting of liquefaction and nonliquefaction field case histories in the Imperial Valley using the electric cone penetration test (CPT). Subsurface testing of the River Park and Heber Road sites first occurred following the 1979 Imperial Valley earthquake (Bennett et al. 1981, Youd and Bennett 1983). These two sites are rich in information because they have experienced several earthquakes in recent history, have been subjected to moderate levels of strong ground shaking, the liquefiable layers have appreciable fines content, and the sites contain a number of high-quality nonliquefied data points. The recent liquefaction case history database for probabilistic assessment of liquefaction triggering by Moss et al. (2003), is based primarily on data acquired using the modern electric cone following ASTM D5778. Case histories previously explored with a cone not adhering to current ASTM standards may introduce significant epistemic uncertainty into the assessment of liquefaction potential and are considered sub-optimal for probabilistic analysis purposes. This paper describes the acquisition and analysis of modern electric cone data at the Heber Road and River Park sites. These important sites can now be incorporated into the probabilistic CPTbased liquefaction case history database and used for back-analysis of liquefaction triggering. Discussed are the effects of ground motion character and frequency content on liquefaction at these two sites and how this influences the results using a simplified liquefaction procedure.

\section{INTRODUCTION}

There are two general classes of methods for assessment of the potential for seismically induced soil liquefaction: (1) laboratory testing based methods, and (2) empirical methods based on correlations with in situ index testing results. Difficulties associated with sample disturbance and sample reconsolidation render laboratory testing problematic. As a result, correlations based on in situ index tests are widely used in engineering practice. The two most widely used methods are correlations based on Standard Penetration Testing (SPT) and correlations based on Cone Penetration Testing (CPT), as described in Youd et al. (2001).

\footnotetext{
a) Fugro West, Inc., 4820 McGrath St., Suite 100, Ventura, CA 93003; rmoss@fugro.com

b) University of California, Dept. of Civil and Env. Eng., Berkeley, CA 94720-1716

c) University of California, Dept. of Civil and Env. Eng., 5731 Boelter Hall, Los Angeles, CA 90095-1593
} 
Correlations are only as good as the quality of the data on which they are based. Moss and Seed (2004) have presented one of the more recent correlations using CPT data. This correlation was based on a worldwide database of electric CPT tests at sites that both experienced strong seismic ground shaking and had detailed observations made of their field performance following shaking (Moss et al. 2003). In order to minimize the epistemic uncertainty in the data, nonstandard or substandard cone data was eliminated from the database. Mechanical cone data and electrical cone data not adhering to ASTM D5778 are considered less than optimal for probabilistic analysis purposes.

The River Park and Heber Road sites, located in the Imperial Valley of California, are rich in information from a liquefaction database perspective. These sites have experienced several seismic events, liquefaction has been observed after strong ground shaking, the liquefiable layers are high in fines content, and nonliquefied locations are well documented. The importance of nonliquefied locations should not be underestimated since their proximity to locations that did liquefy provide additional data points for establishing the empirical correlations and give boundaries to the levels of shaking and geotechnical conditions necessary to reach liquefaction triggering. These sites were originally tested using the mechanical and electrical cone following the 1979 Imperial Valley earthquake (Bennett et al. 1981, Douglas and Martin 1982, Youd and Bennett 1983). The importance of these sites for probabilistic triggering analysis warranted retesting that provided as unbiased subsurface measurements as possible. Described in this paper is the retesting of these two sites with a modern electric cone for the purpose of including this information in the probabilistic CPT-based liquefaction database. A complete description of this research can be found in Moss et al. (2004).

\section{REGIONAL TECTONICS, GEOMORPHOLOGY, AND SEISMICITY}

The River Park and Heber Road sites both lie within the Imperial Valley, near the U.S./Mexico border, in southern California (Figure 1). The Imperial Valley is located in the central part of the Salton Basin, a basin that has been formed due to tectonic rifting, the same crustal rifting that is associated with the Sea of Cortez in Baja California. The Imperial Valley is now a deep sediment valley filled with over 6,000 meters of sediment deposited over the last 4 million years (Sharp 1982).

Parts of the Salton Basin are where ancient Lake Cahuilla periodically resided. This ancient lake has periodically filled the basin (including four times between 700 A.D. and 1580 A.D) fed by the changing course of the Colorado River (Youd and Bennett 1983). The Salton Sea now fills the lower part of the basin and was formed when the Colorado River jumped its course, with the aid of an irrigation mishap, and ran unchecked from 1905 to 1907. Such changes in depositional environment, from lacustrine to alluvial and back again are responsible for the surficial and deeper stratigraphy in the Imperial Valley, something that must be kept in mind when performing detailed site investigations in this area.

The Imperial Valley is located at the southern reach of the San Andreas Fault system. Mapped seismogenic faults in the region include the San Andreas Fault to the north, the Imperial and Brawley faults within the valley (Figure 1), the Mexicali Fault to the south 


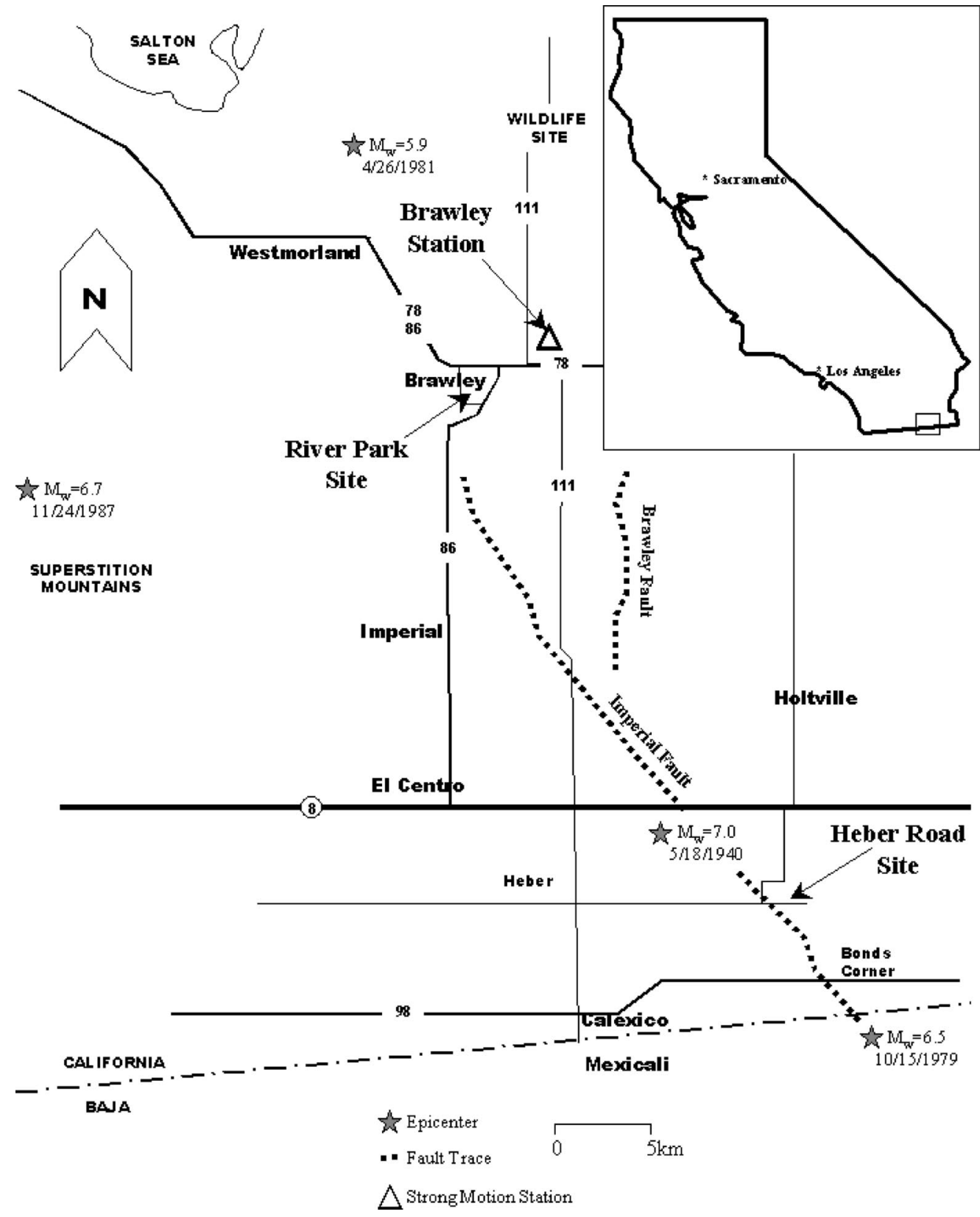

Figure 1. Regional map showing locations of investigated sites, epicentral locations of recent earthquakes, and approximate locations of fault traces. 
across the US/Mexico border, the Elsinore Fault along the southwest edge of the Salton Basin, and the Superstition Hills and Superstition Mountain faults to the west.

This area has experienced a high rate of seismicity in recent years. Of particular interest are the $1940 \mathrm{M}_{\mathrm{w}}=7.0$ El Centro, $1979 \mathrm{M}_{\mathrm{w}}=6.5$ Imperial Valley, $1981 \mathrm{M}_{\mathrm{w}}=5.9$ Westmorland, and $1987 \mathrm{M}_{\mathrm{w}}=6.7$ Superstition Hills events. The epicentral locations of primary rupture for these earthquakes are shown in Figure 1.

\section{PREVIOUS FIELD TESTING}

A significant amount of liquefaction was observed following the 1979 Imperial Valley earthquake. This event produced surface fault rupture along a $35-\mathrm{km}$ trace of the Imperial Fault, the same fault that ruptured in the 1940 El Centro event (Bennett et al. 1981). Two sites of pronounced liquefaction, at River Park in the town of Brawley, and at Heber Road south of Holtville, were investigated by Michael J. Bennett and Prof. T. Leslie Youd of the USGS (Bennett et al. 1981, Youd and Bennett 1983) following the 1979 event.

Subsurface investigations were conducted between December of 1979 and May of 1982 to quantify the in situ soil conditions. Testing included standard penetration tests with continuous sampling, thin walled tube sampling, and mechanical cone penetration tests. The extent of liquefaction and lateral spreading was carefully documented. Grain size analysis and plasticity tests were performed on disturbed samples from the SPT, relatively undisturbed thin walled tube samples, and surface samples of boil ejecta. The subsurface conditions were well characterized resulting in highly detailed cross sectional profiles of both sites. These cross sections are presented subsequently as Figures 3 and 5 .

Additional site investigations and analyses were carried out over the years relating to these sites and the subsequent 1981 and 1987 earthquakes (e.g., Douglas and Martin 1982, Bennett et al. 1984, Youd 1984, and Youd and Wieczorek 1984).

\section{SITE DESCRIPTION}

\section{RIVER PARK}

River Park is a rodeo grounds located in the city of Brawley (Figure 1). River Park, also known as Cattle Call Arena, is situated in the flood plain of the New River (Figure 2). Of interest for liquefaction studies are the near surface fluvial deposits that are present across the site.

Subsurface investigations by Bennett (1981) revealed that River Park stratigraphy was composed of three main soil layers (Figure 3). Unit A, the upper soil layer, consists of loose, brown, sandy silts grading to clayey silts. The sandy silts are interpreted as flood plain deposits and the clayey silts from a flood basin environment. It is likely that meandering of the nearby river produced these type of deposits in succession.

Unit B, the middle soil layer, is predominantly fine-grained silty clay and clay. The clay varies across the site in color and composition, with generally a high organic content. These deposits likely formed in a back swamp depositional environment. 


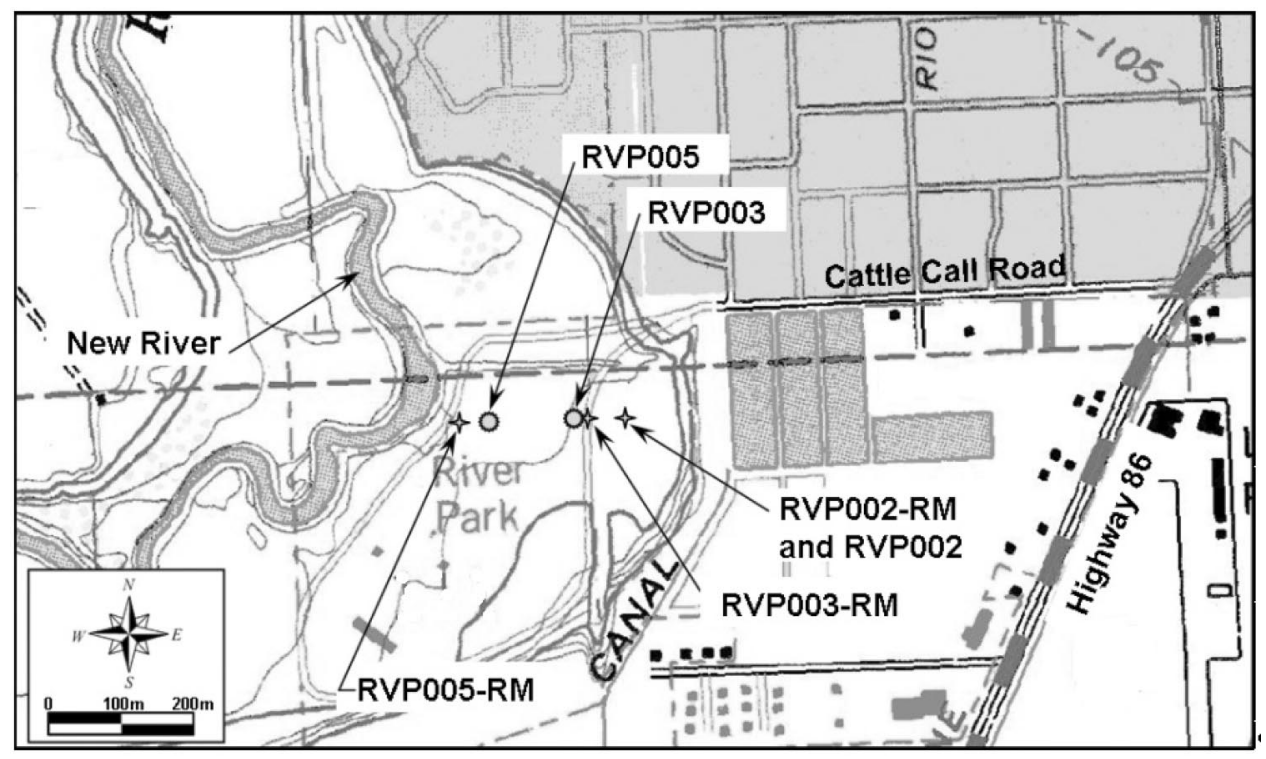

Figure 2. Map of the River Park site, Brawley, California. Shown are the locations of the old (RVP00X) and new (RVP00X-RM) CPT tests.

Unit C, the lower unit, is a generally dense, well-sorted fine sand. The sand appears to be massive with a slight change in color with depth. The upper part of this unit is noticeably less dense than the lower part.

Hundreds of sand boils, slumping, and surface cracking occurred at the River Park site as a result of the 1979 Imperial Valley earthquake (Youd and Bennett 1983). Sand boil ejecta was collected and traced to both Units A and C. Liquefaction is estimated to have occurred throughout Unit A, and in the loose upper portion of Unit C.

This site was investigated following the 1981 Westmorland and 1987 Superstition Hills earthquakes as well. No surface manifestations of liquefaction were recorded after either of these two events thus indicating that the site is sensitive to the amount of seismic shaking involved or that densification of the layers after the 1979 event occurred. In this report, we confine our assessment of liquefaction to Unit A because an average it shows a lower cyclic resistance ratio than the upper portion of Unit C.

\section{HEBER ROAD}

Heber Road is located near the Mexico border south of Holtville and northwest of Bonds Corner (Figure 1). The testing at the site occurred along Heber Road, adjacent to an irrigation canal and the northern boundary of Heber Dunes County Park (Figure 4). Of interest at this site are fluvial deposits from a relic river channel of the Alamo River.

Subsurface investigation by Bennett et al. (1981) found three units of sand and silty sand distributed across the site to a depth of $5 \mathrm{~m}$ (Figure 5). Unit A1 is found along the west side of the abandoned river channel, and is composed of dense to very dense, well- 


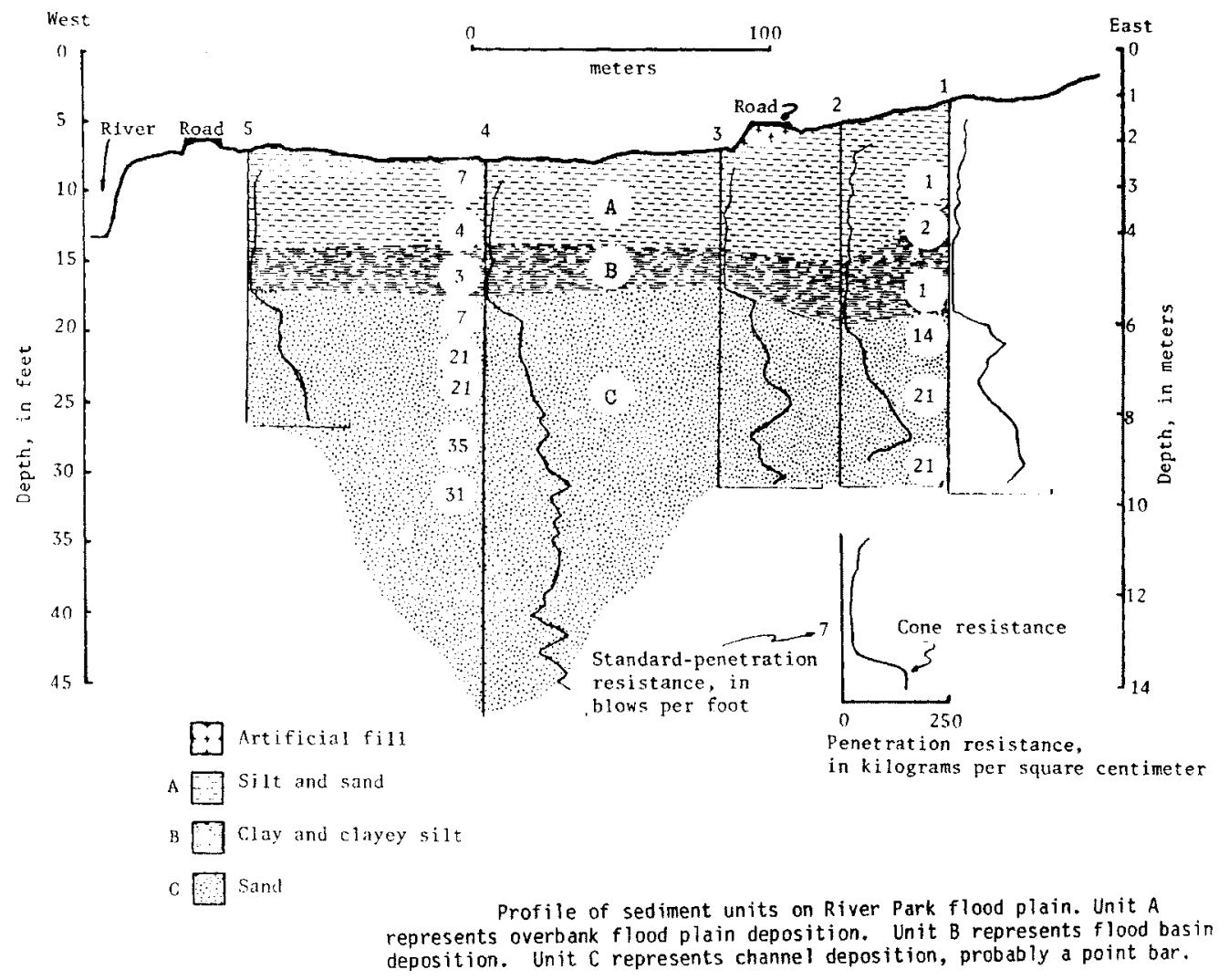

Figure 3. River Park cross section from Bennett et al. (1981). Locations of RVP002, 003, and 005 are shown on Figure 2.

sorted, very fine-grained sand. This unit is upward fining, has horizontal laminations in the lower portion, and ripple beds in the upper portion thus suggesting a river point bar origin.

Unit A2 is composed of very loose, moderately sorted silty sand and sand. Bennett et al. (1981) used aerial photos, the presence of fresh water gastropods, and geomorphic interpretation to determine that this deposit is composed of channel sediments from the abandoned river channel.

Finally, Unit A3, located along the east side of the channel, consists of medium dense, moderately sorted sand and silty sand. This deposit was interpreted to be a natural levee and overbank deposit based on the grain size distribution and its location in relation to Units A1 and A2 (Bennett 1981).

The 1979 Imperial Valley earthquake caused liquefaction and a large lateral spread to occur at the Heber Road site. The lateral spread was approximately $160 \mathrm{~m}$ wide and $100 \mathrm{~m}$ long, and disrupted the pavement as it spread across the road, the adjacent canal, 


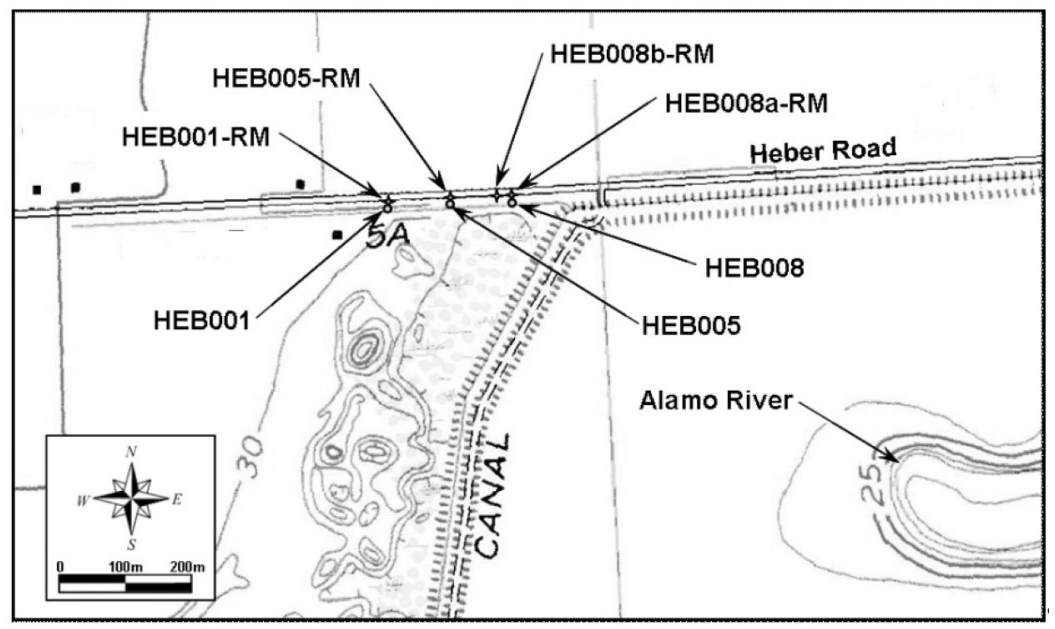

Figure 4. Map of the Heber Road site, Imperial County, California. Shown are the locations of the old (HEB00X) and new (HEB00X-RM) CPT tests.

and into the dunes. Sand boils were found on the lateral spread and along the spread margins. Further studies of this site were carried out by Martin and Douglas (1982), Bierschwale and Stokoe (1984), and Norton (1983).

The Heber Road site was inspected following the 1987 Superstition Hills earthquakes as well. No surface manifestation of liquefaction was recorded after this event. In this paper, we perform assessments of liquefaction of all three soil units (A1, A2, A3) for the 1979 and 1987 earthquakes.

\section{NEW FIELD TESTING}

\section{RECONNAISSANCE}

Previous CPT soundings were located as accurately as possible. The information available on previous CPT locations included maps, figures, photos from the literature (Bennett et al. 1981, Youd and Bennett 1983, Youd 1985), UTM coordinates supplied by Michael J. Bennett, and field notes provided by Prof. T. Leslie Youd.

Prof. Youd also assisted in locating the previous CPT soundings in the field. Several field markers such as power poles, canals and trees remained unchanged since the previous investigations and thus aided in the field location process. Unfortunately, the UTM coordinates that had been previously collected were generated using an unknown baseline and therefore their reference datum could not be resolved. Thus, the locations of the previous CPT testing points were based mainly on their visual field location. Using these methods the estimated confidence in relocating the old CPT test locations was determined to be on the order of $1 \mathrm{~m}$. Figures 2 and 4 show the locations of the old and new CPT soundings, where the new soundings have the suffix RM to differentiate them from the old tests. 


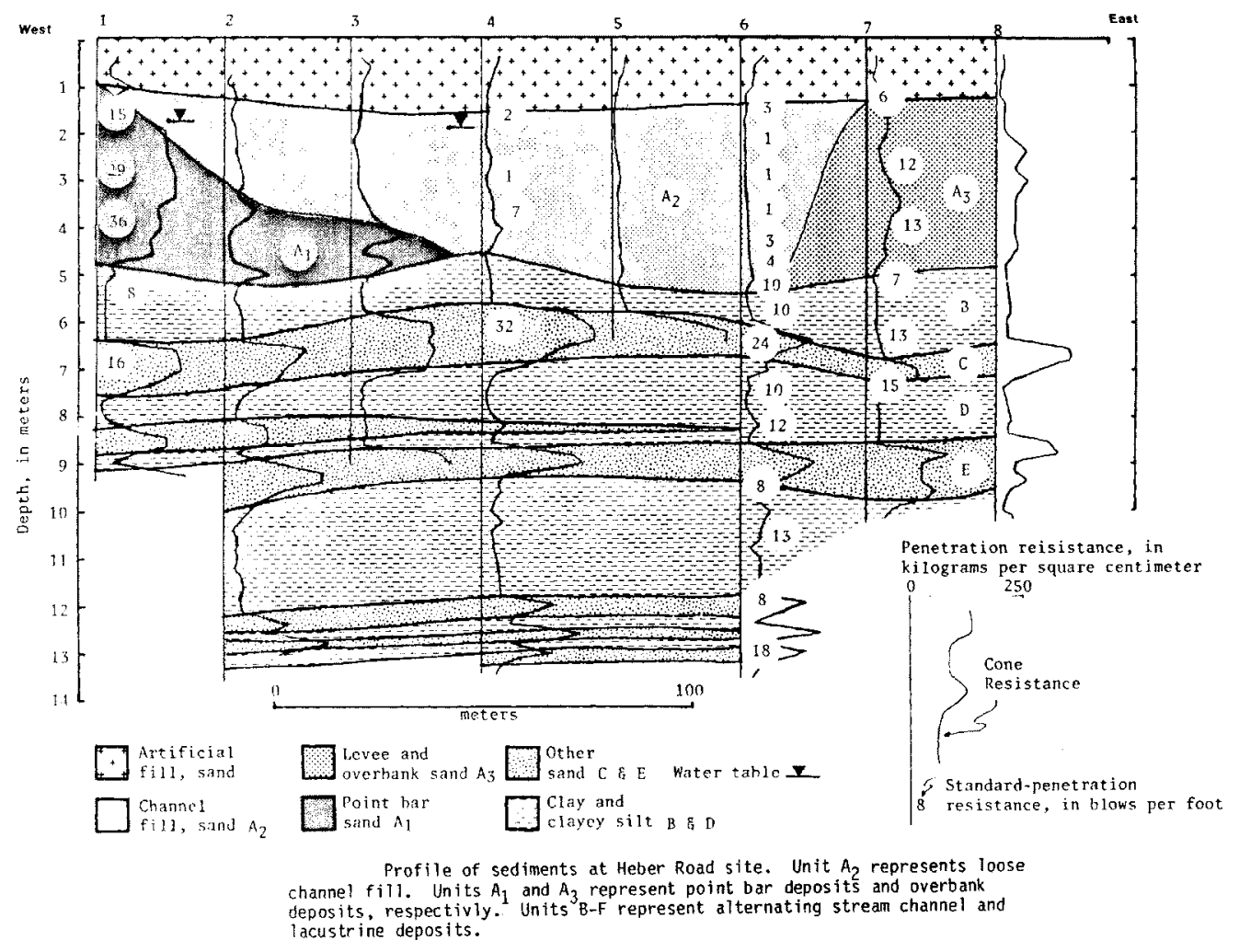

Figure 5. Heber Road cross section from Bennett et al. (1981). Locations of HEB001, 005, and 008 are shown in Figure 4.

\section{DGPS}

As part of this investigation, we felt it necessary to ensure that the location of the new CPT locations were surveyed to a high degree of accuracy. Surveying was performed using a differential global positioning system (DGPS) with sub-meter absolute accuracy. For DGPS locating we used a Trimble Ag132 differential ready GPS unit that is capable of receiving remote sources of differential correction. As opposed to typical hand-held GPS unit surveys, which rely solely on the constellation of satellites already available by the U.S. Dept. of Defense, differential GPS relies on the collection of an additional base station correction to account for and minimize the various errors associated with nondifferential GPS surveys.

We used the differential signal provided by Omnistar's North American West satellite in real-time mode in order to provide instantaneous positions at the sub-meter level. GPS positional data collected for this project was obtained using typically seven constellation satellites at a dilution of position (DOP) value of 2 and a signal to noise ratio $(\mathrm{S} / \mathrm{N})$ of at 
Table 1. GPS data of CPT locations

\begin{tabular}{|c|c|c|c|c|c|c|}
\hline Location & $\begin{array}{c}\text { Easting } \\
\text { (m) }\end{array}$ & $\begin{array}{l}\text { Northing } \\
\text { (m) }\end{array}$ & $\begin{array}{c}\text { NAVD88 } \\
\text { Elevation } \\
\quad(\mathrm{m})\end{array}$ & Latitude & Longitude & $\begin{array}{c}\text { Ellipsoid } \\
\text { Height } \\
\text { (m) }\end{array}$ \\
\hline \multicolumn{7}{|c|}{ River Park Site (UTM 11S, NAD83) } \\
\hline RVP002-RM & 635294.0 & 3648838.5 & -45.0 & $\mathrm{~N} 32^{\circ} 58^{\prime} 10.28^{\prime \prime}$ & $\mathrm{W} 115^{\circ} 33^{\prime} 08.15^{\prime \prime}$ & -79.4 \\
\hline RVP003-RM & 635243.3 & 3648839.3 & -45.7 & $\mathrm{~N} 32^{\circ} 58^{\prime} 10.33^{\prime \prime}$ & $\mathrm{W} 115^{\circ} 33^{\prime} 10.10^{\prime \prime}$ & -80.1 \\
\hline RVP005-RM & 635071.5 & 3648839.2 & -47.8 & $\mathrm{~N} 32^{\circ} 58^{\prime} 10.40^{\prime \prime}$ & $\mathrm{W} 115^{\circ} 33^{\prime} 16.71^{\prime \prime}$ & -82.2 \\
\hline \multicolumn{7}{|c|}{ Heber Road Site (UTM 11S, NAD83) } \\
\hline HEB001-RM & 651143.6 & 3622560.6 & 13.5 & $\mathrm{~N} 32^{\circ} 43^{\prime} 49.78^{\prime \prime}$ & $\mathrm{W} 115^{\circ} 23^{\prime} 13.23^{\prime \prime}$ & -21.1 \\
\hline HEB005-RM & 651235.9 & 3622562.3 & 12.0 & $\mathrm{~N} 32^{\circ} 43^{\prime} 49.79^{\prime \prime}$ & $\mathrm{W} 115^{\circ} 23^{\prime} 09.69^{\prime \prime}$ & -22.6 \\
\hline HEB008a-RM & 651325.8 & 3622563.6 & 12.6 & $\mathrm{~N} 32^{\circ} 43^{\prime} 49.79^{\prime \prime}$ & $\mathrm{W} 115^{\circ} 23^{\prime} 06.24^{\prime \prime}$ & -22.0 \\
\hline HEB008b-RM & 651304.4 & 3622563.8 & 10.1 & $\mathrm{~N} 32^{\circ} 43^{\prime} 49.80^{\prime \prime}$ & $\mathrm{W} 115^{\circ} 23^{\prime} 07.06^{\prime \prime}$ & -24.5 \\
\hline
\end{tabular}

Note: Maximum precision of data is 1 meter or approximately 0.03 seconds of latitude/longitude at these locations.

least 11. This data was therefore collected at a high level of accuracy; typical values of less than 4 DOP and a S/N ratio greater than 6 are normally recommended for differential GPS.

Data was collected in latitude/longitude and UTM coordinate systems, both referenced to the NAD83 three-dimensional datum. For our study sites, the UTM zone is $11 \mathrm{~S}$. Elevation is referenced to the NAVD88 vertical datum and was obtained through a conversion from the NAD83 ellipsoid using the GEOID99 geoid. Data for both sites are included in Table 1 and correlate to the site maps for the River Park and Heber Road sites in Figures 2 and 4. The horizontal error due to epistemic uncertainty in this surveying method is estimated to be approximately 1 meter.

\section{CPT}

The University of California, Los Angeles, Network for Earthquake Engineering Simulation (nees@UCLA) cone penetration testing truck was used in the field investigations. The nees@UCLA CPT truck is a Hogentogler ${ }^{\mathrm{TM}}$ rig equipped with a seismicpiezocone to characterize soil consistency, pore water pressure and shear wave velocities. The rig has a 20-ton hydraulic push capacity and side augers to provide the necessary reaction force. A fully automatic 5-channel data acquisition system records measurements of cone tip resistance, sleeve friction, probe inclination, pore water pressure, and shear wave velocities. The cone has a $10 \mathrm{~cm}^{2}$ tip (60 degree apex), with a $150 \mathrm{~cm}^{2}$ sleeve, a pore pressure transducer located directly behind the tip, and was pushed at a penetration rate of $2 \mathrm{~cm} / \mathrm{sec}$. The electric CPT soundings for this study were located as close as possible to the original CPT soundings from Bennett et al. (1981), and Youd and Bennett (1983).

Muddy conditions at the River Park site limited the access to the perimeter of the rodeo grounds, therefore the electric soundings RVP003 and RVP005 are offset a few meters from the previous soundings, although still along the same cross-section line heading. Electric CPT soundings at the Heber Road site were located at approximately 
the same locations as the previous soundings. Heber Road Unit A3 was tested twice, HEB008a and 008b, to gather as much information as possible about this nonliquefied deposit.

\section{RESULTS}

The collection of electric CPT data from these two sites adds two liquefaction and seven nonliquefaction case histories to the worldwide database. Four points each are added from the 1979 Imperial Valley and 1987 Superstition Hills earthquakes for the River Park A and Heber Road A1, A2, and A3 soil units, while only one point is added from the 1981 Westmorland earthquake from the River Park A soil unit. The Heber Road units were not assessed for the 1981 Westmorland earthquake because this event was located far from this site and did not result in a significant level of shaking. The pertinent data for each of the nine case histories added to the database are summarized in Table 2 for each of the three earthquakes and their effects on the individual soil layers investigated. The processing techniques used are described in detail in Moss (2003).

The estimates of strong ground shaking shown in Table 2 were taken from Cetin et al. (2000), in which site response analyses for these two Imperial Valley sites were performed. The site response analyses were based on detailed stratigraphy of the sites and strong ground motion recordings from nearby instruments. The mean and variance of the peak ground acceleration (PGA) were calculated in each analysis, thereby giving a best estimate of the accelerations experienced.

The reported depth to the water table is based on values reported in Cetin et al. (2000), and pore pressure measurements made in the field. The Cetin et al. (2000) values are based on previous water table measurements as reported in the literature. The depth to the water table, like the other variables in this probabilistic assessment, is treated as an uncertain parameter described by a frequency distribution. The distribution of the depth to water table is assumed to be normal, with a mean based on best estimates from current and previous measurements, and a standard deviation of 0.3 meters. Treating the water table as an uncertain parameter can account for different water table depths during different earthquakes due to seasonal or other fluctuations.

Fines contents $(\% \mathrm{FC})$ from previous field testing where subsurface samples were retrieved have been assessed by Cetin et al. (2000). Cetin et al. include a comparison of reported values and values from Seed et al. (1984), which for these two sites are the same. The mean fines contents and USCS classifications are as follows: Heber Road Unit A1-SP soil class with 25\% fines content; Heber Road Unit A2-SM soil class with 29\% fines content; Heber Road Unit A3-SM soil class with 37\% fines content; and River Park Unit A-SM soil class with 80\% fines content.

Complete details of the CPT-based analysis for each case history are in Moss et al. (2004). The mean results for the case histories are shown in relation to probabilistic liquefaction triggering curves from Moss and Seed (2004) in Figures 6 and 7. Figure 6 shows the new case histories, uncorrected for friction ratio or "apparent" fines content, in relation to the probabilistic liquefaction triggering curves. Figure 7 shows the new case histories, corrected for friction ratio, relative to the triggering curves and the existing worldwide database. The tip resistance corrected for friction ratio or "apparent" 
Table 2. Summary of liquefaction and nonliquefaction case histories

\begin{tabular}{|c|c|c|c|c|c|c|c|c|c|c|c|c|c|c|c|}
\hline $\begin{array}{l}\text { EVENT } \\
1979 \text { Imperial Valley } \\
\text { SITE } \\
\text { DESCRIPTION }\end{array}$ & $\begin{array}{c}\mathrm{M}_{\mathrm{w}} \\
6.50 \\
\text { LIQ? }\end{array}$ & $\begin{array}{c} \pm \\
0.13 \\
\text { DATA } \\
\text { CLASS }\end{array}$ & $\begin{array}{l}\text { Median Crit. } \\
\text { Depth }(\mathrm{m})\end{array}$ & \pm & $\begin{array}{l}\text { w.t. } \\
(\mathrm{m})\end{array}$ & $\begin{array}{l}\mathrm{a}_{\max } \\
(\mathrm{g})\end{array}$ & \pm & CSR & \pm & $\begin{array}{c}\mathrm{q}_{\mathrm{c}, 1} \\
(\mathrm{MPa})\end{array}$ & \pm & $\begin{array}{c}\mathrm{R}_{\mathrm{f}} \\
(\%)\end{array}$ & \pm & $\begin{array}{l}\mathrm{q}_{\mathrm{c}, 1, \bmod } \\
(\mathrm{MPa})\end{array}$ & CSRN \\
\hline River Park A & $\mathrm{Y}$ & $\mathrm{C}$ & 1.50 & 0.33 & 0.30 & 0.16 & 0.05 & 0.17 & 0.07 & 7.99 & 6.95 & 1.28 & 1.66 & 8.60 & 0.14 \\
\hline Heber Road A1 & $\mathrm{N}$ & $\mathrm{B}$ & 3.05 & 0.38 & 1.80 & 0.47 & 0.05 & 0.33 & 0.07 & 25.84 & 11.32 & 1.21 & 0.80 & 26.58 & 0.27 \\
\hline Heber Road A2 & Y & $\mathrm{B}$ & 3.50 & 0.58 & 1.80 & 0.47 & 0.05 & 0.35 & 0.10 & 4.51 & 1.03 & 0.71 & 0.29 & 4.73 & 0.29 \\
\hline Heber Road A3 & $\mathrm{N}$ & B & 3.40 & 0.45 & 1.80 & 0.47 & 0.05 & 0.33 & 0.09 & 8.91 & 5.71 & 0.92 & 1.00 & 9.35 & 0.27 \\
\hline $\begin{array}{l}\text { EVENT } \\
1981 \text { Westmorland }\end{array}$ & $\begin{array}{l}\mathrm{M}_{\mathrm{w}} \\
5.90\end{array}$ & $\begin{array}{c} \pm \\
0.15\end{array}$ & & & & & & & & & & & & & \\
\hline $\begin{array}{l}\text { SITE } \\
\text { DESCRIPTION }\end{array}$ & LIQ? & $\begin{array}{c}\text { DATA } \\
\text { CLASS }\end{array}$ & $\begin{array}{l}\text { Median Crit. } \\
\text { Depth (m) }\end{array}$ & \pm & $\begin{array}{l}\text { w.t. } \\
(\mathrm{m})\end{array}$ & $\begin{array}{l}\mathrm{a}_{\max } \\
(\mathrm{g})\end{array}$ & \pm & CSR & \pm & $\begin{array}{c}\mathrm{q}_{\mathrm{c}, 1} \\
(\mathrm{MPa})\end{array}$ & \pm & $\begin{array}{l}\mathrm{R}_{\mathrm{f}} \\
(\%)\end{array}$ & \pm & $\begin{array}{l}\mathrm{q}_{\mathrm{c}, 1, \bmod } \\
(\mathrm{MPa})\end{array}$ & CSRN \\
\hline River Park A & $\mathrm{N}$ & B & 1.50 & 0.33 & 0.30 & 0.17 & 0.02 & 0.19 & 0.04 & 7.99 & 6.95 & 1.28 & 1.66 & 8.64 & 0.14 \\
\hline $\begin{array}{l}\text { EVENT } \\
1987 \text { Superstition Hills }\end{array}$ & $\begin{array}{l}M_{w} \\
6.70\end{array}$ & $\begin{array}{c} \pm \\
0.13\end{array}$ & & & & & & & & & & & & & \\
\hline $\begin{array}{l}\text { SITE } \\
\text { DESCRIPTION }\end{array}$ & LIQ? & $\begin{array}{c}\text { DATA } \\
\text { CLASS }\end{array}$ & $\begin{array}{l}\text { Median Crit. } \\
\text { Depth (m) }\end{array}$ & \pm & $\begin{array}{l}\text { w.t. } \\
(\mathrm{m})\end{array}$ & $\begin{array}{l}\mathrm{a}_{\max } \\
(\mathrm{g})\end{array}$ & \pm & CSR & \pm & $\begin{array}{c}\mathrm{q}_{\mathrm{c}, 1} \\
(\mathrm{MPa})\end{array}$ & \pm & $\begin{array}{l}\mathrm{R}_{\mathrm{f}} \\
(\%)\end{array}$ & \pm & $\begin{array}{l}\mathrm{q}_{\mathrm{c}, 1, \mathrm{mod}} \\
(\mathrm{MPa})\end{array}$ & CSRN \\
\hline River Park A & $\mathrm{N}$ & C & 1.50 & 0.33 & 0.30 & 0.19 & 0.02 & 0.19 & 0.09 & 7.99 & 6.95 & 1.28 & 1.66 & 8.64 & 0.16 \\
\hline Heber Road A1 & $\mathrm{N}$ & $\mathrm{B}$ & 3.05 & 0.38 & 1.80 & 0.16 & 0.02 & 0.12 & 0.03 & 25.84 & 11.32 & 1.21 & 0.80 & 26.31 & 0.10 \\
\hline Heber Road A2 & $\mathrm{N}$ & $\mathrm{B}$ & 3.50 & 0.58 & 1.80 & 0.15 & 0.02 & 0.12 & 0.03 & 4.51 & 1.03 & 0.71 & 0.29 & 4.65 & 0.10 \\
\hline Heber Road A3 & $\mathrm{N}$ & B & 3.40 & 0.45 & 1.80 & 0.13 & 0.02 & 0.11 & 0.03 & 8.91 & 5.71 & 0.92 & 1.00 & 9.17 & 0.09 \\
\hline
\end{tabular}

Notes: $\mathrm{M}_{\mathrm{w}}=$ moment magnitude, $\pm=$ variance reported as 1 standard deviation, LIQ?=did liquefaction occur Yes or No, Crit.=critical, w.t. $=$ mean depth to water table with a fixed standard deviation of $0.3 \mathrm{~m}, \mathrm{a}_{\max }=$ geometric mean of the peak horizontal ground acceleration, $\overline{C S R}=$ cyclic stress ratio, $\mathrm{q}_{\mathrm{c}, 1}=$ normalized tip resistance, $\mathrm{R}_{\mathrm{f}}=$ friction ratio, $\mathrm{q}_{\mathrm{c}, 1, \mathrm{mod}}=$ normalized tip resistance corrected for friction ratio, $\mathrm{CSRN}=$ magnitude corrected cyclic stress ratio. 


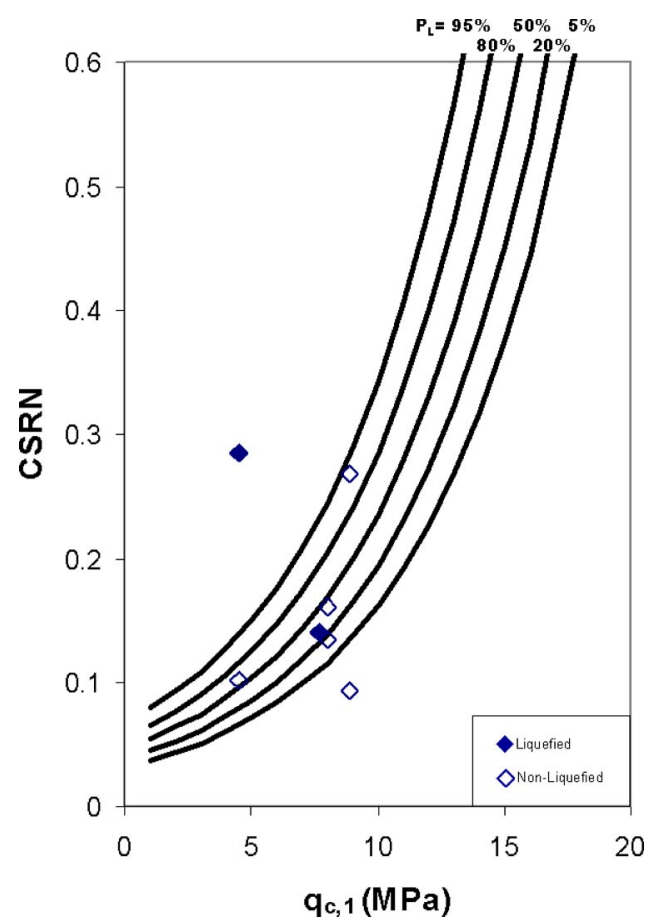

Figure 6. New liquefaction/nonliquefaction case histories (diamonds) shown with probabilistic liquefaction triggering curves, for $\mathrm{M}_{\mathrm{w}}=7.5$ and $\sigma_{\mathrm{v}}^{\prime}=1 \mathrm{~atm}$, from Moss and Seed (2004). Solid symbols are the mean values of liquefaction case histories and hollow symbols are the mean values of nonliquefaction case histories. Note that data points for Heber Unit A1 are not included on this plot since $\mathrm{q}_{\mathrm{c}, 1}>20 \mathrm{MPa}$.

fines content $\left(\mathrm{q}_{\mathrm{c}, 1, \mathrm{mod}}\right)$ can be considered analogous to a clean sand corrected blow count $\left(\mathrm{N}_{1,60, \mathrm{CS}}\right)$. Note that because of the large tip resistance measured in Heber Road Unit A1 $\left(\mathrm{q}_{\mathrm{c}, 1}>20 \mathrm{MPa}\right)$, the case histories for these points do not appear on the triggering plots.

\section{ANALYSIS}

These sites have been explored and analyzed by numerous researchers and in relation to the worldwide database of liquefaction/nonliquefaction case histories can be considered to have minimal epistemic uncertainty in terms of the collection and processing of the data. Of the new data, four nonliquefied and one liquefied data points fall within the boundary zone of triggering, as indicated by the lines of probability of liquefaction. This zone of "mixing" of the liquefied and nonliquefied data, is the probabilistic boundary zone of triggering (between 5\% and 95\% probability). These five points are of particular import because their location in relation to the curves gives them the most influence on the location of the curves; as the points are closer to the boundary their influence on the 


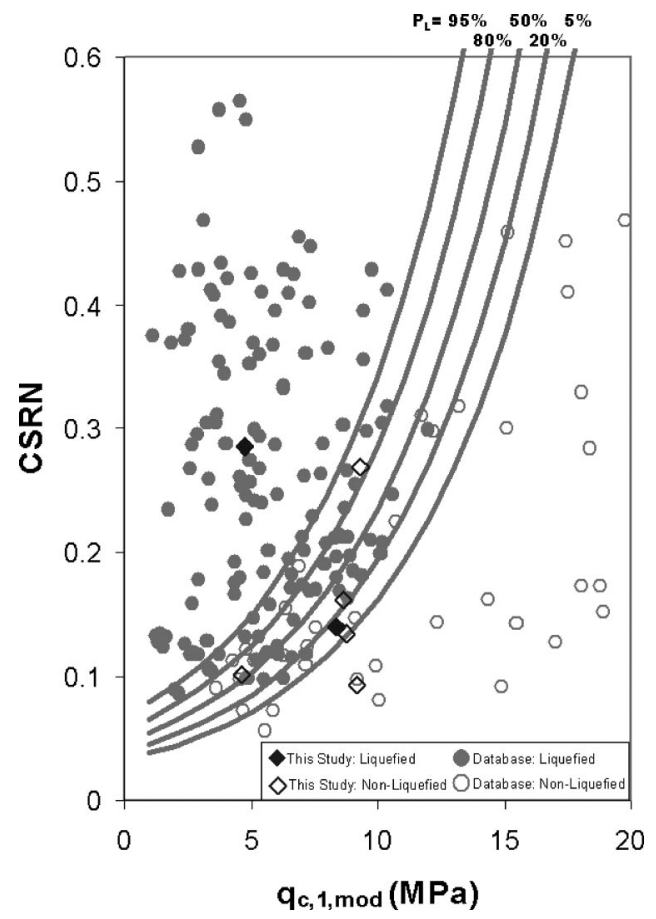

Figure 7. New liquefaction/nonliquefaction case histories (diamonds), corrected for friction ratio, shown with probabilistic liquefaction triggering curves and the worldwide database (circles), for $\mathrm{M}_{\mathrm{w}}=7.5$ and $\sigma_{\mathrm{v}}^{\prime}=1 \mathrm{~atm}$, from Moss and Seed (2004). Solid symbols are the mean values of liquefaction case histories and hollow symbols are the mean values of nonliquefaction case histories. Note that data points for Heber Unit A1 are not included on this plot since $\mathrm{q}_{\mathrm{c}, 1}>20 \mathrm{MPa}$.

location of the curves is greater. Based on the location of the data the new points do not perceptibly alter the location of the probability curves, but reinforce and bolster the current location of the curves.

It is interesting to note that River Park Unit A was observed to have liquefied during the 1979 Imperial Valley earthquake which produced an uncorrected CSR $=0.17$, yet no surface manifestation of liquefaction was observed during the 1981 Westmorland and 1987 Superstition Hills earthquake that resulted in an uncorrected CSR $=0.19$ for both events. Correcting the CSR for duration using a magnitude correlated duration weighting factor $\left(\mathrm{DWF}_{\mathrm{M}}\right)$ (Seed et al. 2003) the CSRN values become 0.14, 0.14, and 0.16 for the 1979, 1981, and 1987 events, respectively. Any further discrepancy between CSRN and the evidence of liquefaction may be due to a number of factors:

- First, the tip resistance of a liquefied layer is usually measured after liquefaction, and therefore after densification that can occur following liquefaction. The CPT measurements of Unit A were performed after liquefaction occurred. Therefore, the measurements may better represent the post-liquefaction resistance of the 

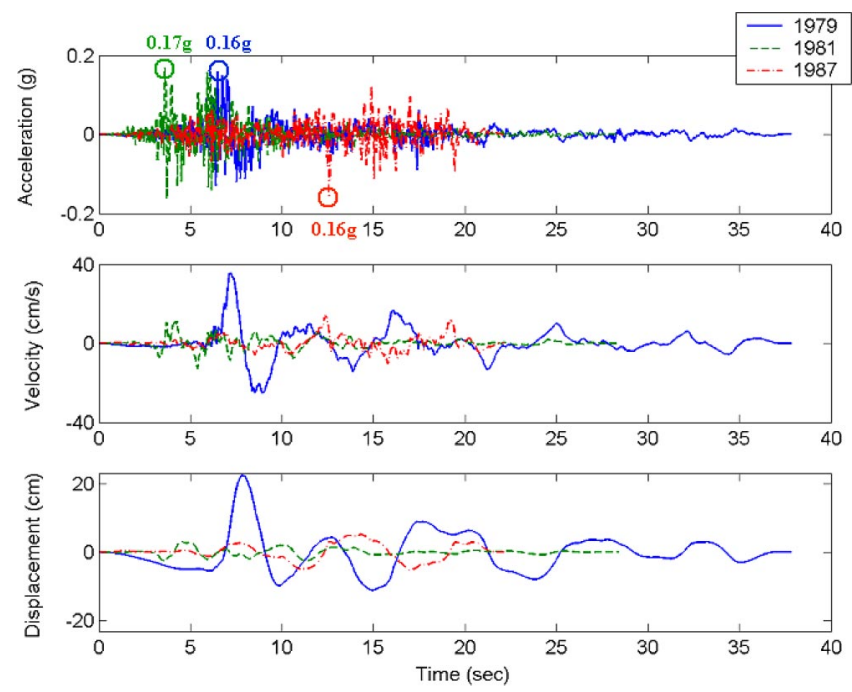

Figure 8. Acceleration, velocity, and displacement time histories for the 1979 Imperial Valley, 1981 Westmorland, and 1987 Superstition Hills earthquakes, recorded at the Brawley Station (orientation 225 degrees). Peak ground acceleration for each event is shown.

soil. However, for soils that are near critical state when liquefaction occurs, it has been hypothesized that little overall densification results (Moss 2003).

- Second, the characteristics of the ground shaking may be different between the earthquakes. Peak ground acceleration is only a single measure of complexity that is better characterized by considering frequency content, duration, and other characteristics of the strong ground shaking. Figure 8 shows recordings of the 1979 Imperial Valley, 1981 Westmorland, and 1987 Superstition earthquakes, all from the Brawley Station located approximately $5 \mathrm{~km}$ ENE from the River Park site and $32 \mathrm{~km}$ NNW from the Heber Road site (Figure 1). The acceleration, velocity, and displacement time histories are plotted for the 225-degree instrument orientation.

The significant duration (D5-95) for the three events are as follows: 14.87 sec for the 1979 event, $8.23 \mathrm{sec}$ for the 1981 event, and $13.53 \mathrm{sec}$ for the 1987 event. The 1979 event shows higher peak velocities (and thus higher strains within the soil profile) with several velocity pulses present, as well as higher peak displacements. Figure 9 shows a comparison of response spectra of the three events with the 1979 event having a higher response over a large frequency range, particularly in the longer periods that coincide with site periods for deep soil profiles such as found at the River Park site. It has also been noted by Cetin et al. (2000) that the 1979 event had directivity effects that most likely resulted in the duration and velocity trends observed above. Therefore, even though the 1981 and 1987 events resulted in higher average peak ground accelerations at the site, the 1979 event likely generated higher soil strains and thus was more likely to liquefy the site. 


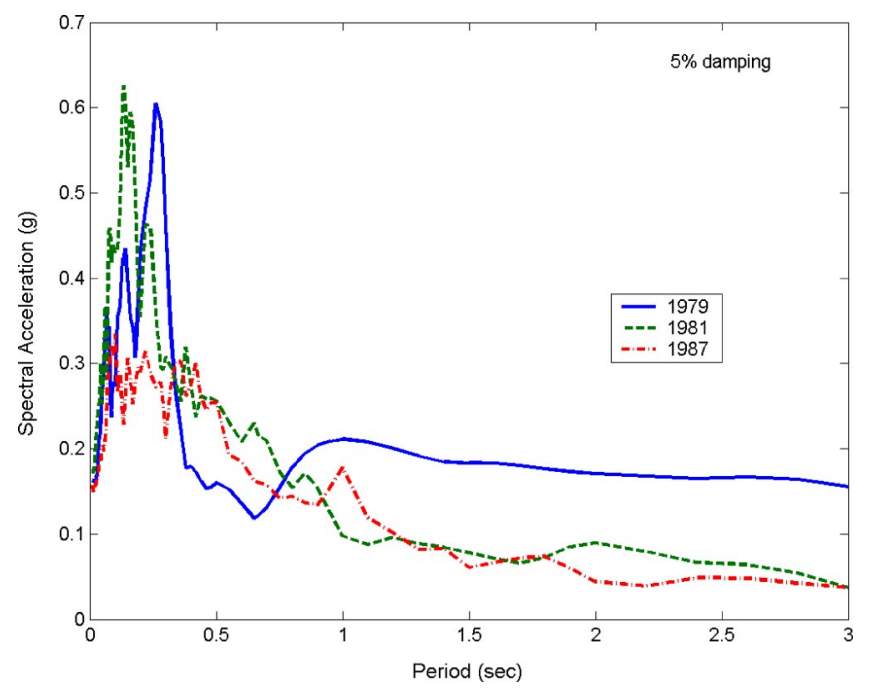

Figure 9. Comparison of response spectra showing the 1979 Imperial Valley, 1981 Westmorland, and 1987 Superstitious Hills earthquakes recorded at the Brawley Station (orientation 225 degrees).

- Third, site response of a deep soft site like the River Park site will exhibit strong nonlinearity once a threshold strain is reached, owing to a "bend-over" effect of the response. It is apparent from site response analyses (Cetin et al. 2000) that more strain softening resulted from the 1979 event than the 1981 and 1987 events. Thus, this strain softening would have decreased the PGA for the 1979 event.

- Fourth, different water table depths at the time of the events could have resulted in different values of CSR. A lower water table increases the effective stress and thereby increases the CSR. It is possible that the River Park site had different water table depths during the 1981 and 1987 events. However, using a best estimate of the depth to water table, and treating the water table as an uncertain parameter accounts for a certain amount of water table fluctuations.

Based on these factors, we find that the higher CSRN of the 1987 event is an artifact of the simplified procedure used in assessing liquefaction, which only accounts for strong ground shaking through PGA. These results reinforce the benefits of a probabilistic triggering analysis that can quantify uncertainties within the simplified model (parameter uncertainty) and uncertainties that the simplified model fails to capture (model error).

As a final note, a typical comparison plot of the previous mechanical and electrical cone soundings with the recent electric cone soundings are shown in Figure 10 for HEB008. There is little agreement among the different cone tests. However, all three tests generally show an increased tip resistance and decreased friction ratio over the depth range of about 2.0 to 4.5 meters, which represents the levee and overbank sand 


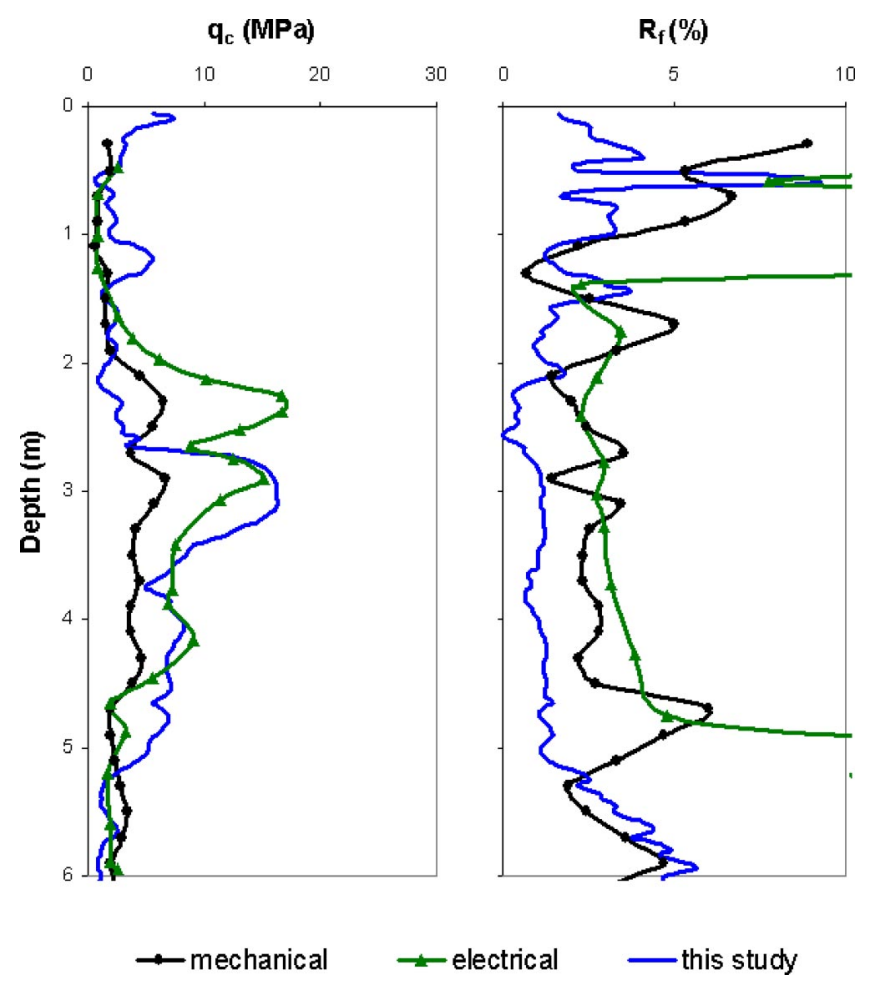

Figure 10. Comparison of previous mechanical and electrical cone soundings with recent electric cone soundings from this study at Heber Road, HEB008.

deposit (Unit A3) at Heber Road. This study did not generate enough data to statistically quantify the variance between the tests. The modern electric cone, as would be expected, is more sensitive to changes in soil resistance and therefore more capable of registering thin layers and seams. Another benefit that the modern electric cone has over the previous mechanical and electrical cone is its repeatability from site to site and from operator to operator.

\section{CONCLUSIONS}

This paper presents nine liquefaction/nonliquefaction case histories from the Imperial Valley that have been retested using the modern electric CPT. These sites were originally tested using cone testing techniques that are now less than optimal for probabilistic assessment of liquefaction. In total, seven nonliquefaction and two liquefaction case histories are added to the existing probabilistic CPT-based liquefaction database. These data points reinforce the location of the probability curves of liquefaction triggering as presented by Moss and Seed (2004). These sites are important to include in the liquefaction database because they have experienced several earthquakes in recent history, have been subjected to moderate levels of strong ground shaking, the liquefiable soils have appreciable fines content, and the sites contain a number of high-quality nonliquefied data 
points. The effects of ground motion character and frequency content on liquefaction at these two sites and how this influenced the results using a simplified liquefaction procedure have been explored.

\section{ACKNOWLEDGMENTS}

Funding for this project was provided by the NSF-sponsored Pacific Earthquake Engineering Research Center (PEER) Lifelines Program via the California Department of Transportation, the California Energy Commission, and Pacific Gas and Electric, and this support is gratefully acknowledged. Thanks are due to Prof. Jon Stewart for his guidance and thoughtful comments, Prof. T. Leslie Youd for his assistance in the field and helpfulness throughout, and Thomas and Peter Nolan (the Hogentogler Brothers) for their help with the CPT rig, including on-the-spot maintenance and repair. Finally, thanks to the anonymous reviewers who helped improve the content and context of this work.

\section{REFERENCES}

Bennett, M. J., Youd, T. L., Harp, E. L., and Wieczorek, G. F., 1981. Subsurface investigation of liquefaction, Imperial Valley earthquake, California, October 15, 1979, USGS Open-File Report 81-502, U.S. Geological Survey, Menlo Park, CA.

Bennett, M. J., McLaughlin, P. V., Sarmiento, J. S., and Youd, T. L., 1984. Geotechnical investigation of liquefaction sites, Imperial Valley, California, USGS Open File Report 84-252, U.S. Geological Survey, Menlo Park, CA.

Bierschwale, J. G., and Stokoe, K. H., II, 1984. Analytical evaluation of liquefaction potential of sands subjected to the 1981 Westmorland earthquake, Geotechnical Engineering Report GR 84-15, University of Texas, Austin.

Cetin, K. O., Seed, R. B., Moss, R. E. S., Der Kiureghian, A., Tokimatsu, K. Harder, L. F., Jr., and Kayen, R. E, 2000. Field case histories for SPT-based in situ liquefaction potential evaluation, U.C. Berkeley Geotechnical Engineering Research Report UCB/GT-2000/09.

Douglas, B. J., and Martin, G. R., 1982. In Situ Testing in Regions Liquefied during the 1979 Imperial Valley Earthquake, Grant No. PFR-8007419, National Science Foundation, Washington, D.C.

Moss, R. E. S., 2003. CPT-Based Probabilistic Assessment of Seismic Soil Liquefaction Initiation, Ph.D. dissertation, University of California Berkeley (http://www.fugrowest.com/ services/earthquake/html/eqengineering.html).

Moss, R. E. S., Seed, R. B., Kayen, R. E., Stewart, J. P., Youd, T. L., and Tokimatsu, K., 2003. Field case histories for CPT-based in situ liquefaction potential evaluation, U.C. Berkeley Geoengineering Research Report No. UCB/GE-2003/04.

Moss, R. E. S., and Seed, R. B., 2004. Probabilistic assessment of seismic soil liquefaction using the CPT, 11th Int. Conf. Soil Dynamics Earthquake Engineering and 3rd Int. Conf. Earthquake Geotechnical Engineering, Berkeley, January 7-9.

Moss, R. E. S., Collins, B. D., Whang, D. H., and Stewart, J. D., 2004. Retesting of Liquefaction and Non-Liquefaction Case Histories in the Imperial Valley Using CPT, Pacific Earthquake Engineering Research (PEER) Center, in press.

Norton, W. E., 1983. In Situ Determination of Liquefaction Potential Using the PGS Probe, Technical Report GL-83-15, U.S. Army Engineer Waterways Experiment Station. 
Seed, H. B., Tokimatsu, K., Harder, L. F., and Chung, R. M., 1984. The Influence of SPT Procedures in Soil Liquefaction Resistance Evaluations, Earthquake Engineering Research Center, University of California, Report UCB/EERC-84/15, Berkeley, CA, October.

Seed, R. B., Cetin, K. O., Moss, R. E. S., Kammerer, A., Wu, J., Pestana, J., Riemer, M., Sancio, R. B., Bray, J. D., Kayen, R. E., and Faris, A., 2003. Recent advances in soil liquefaction engineering: A unified and consistent framework, Earthquake Engineering Research Center, University of California, Report EERC 2003-06, Berkeley, CA.

Sharp, R. V., 1982. Variable rates of later Quaternary strike-slip on San Jacinto fault zone, Southern California, J. Geophys. Res. 86 (B3), 1754-1762.

Youd, T. L., and Bennett, M. J., 1983. Liquefaction sites, Imperial Valley, California, J. Geotech. Eng. 109 (3), 440-457.

Youd, T. L., 1984. Recurrence of liquefaction at the same site, Proceedings of 8th World Conference on Earthquake Engineering, San Francisco, pp. 231-238.

Youd, T. L., and Wieczorek, G. F., 1984. Liquefaction during the 1981 and previous earthquakes near Westmorland, CA, USGS Open-File Report 84-680, U.S. Geological Survey, Menlo Park, CA.

Youd, T. L., 1985. Liquefaction studies in the Imperial Valley, California, Workshop on In Situ Testing Methods for Evaluation of Soil Liquefaction Susceptibility, U.S.-Japan Panel on Wind and Seismic Effects, U.S.-Japan Cooperative Program in Natural Resources, San Francisco, pp. 109-139.

Youd, T. L., Idriss, I. M., Andrus, R. D., Arango, I., Castro, G., Christian, J. T., Dobry, R., Finn, W. D. L., Harder, Jr., L. F., Hynes, M. E., Ishihara, K., Koester, J. P., Liao, S. S. C., Marcuson, III, W. F., Martin, G. R., Mitchell, J. K., Moriwaki, Y., Power, M. S., Robertson, P. K., Seed, R. B., and Stokoe, K. H., II, 2001. Liquefaction resistance of soils: Summary report from the 1996 NCEER and 1998 NCEER/NSF workshops on evaluation of liquefaction resistance of soils, J. Geotech. Geoenviron. Eng. 127 (10), 817-833. 